\title{
PRESENTACIÓN
}

\section{LA UNIVERSIDAD DE AlicANTE Y LOS «EstUdios ARGELINOS»: UNA PUBLICACIÓN NECESARIA}

Argelia ha sido históricamente lugar de refugio y exilio para heterodoxos españoles, moriscos expulsados, berberiscos renegados, mancos de Lepanto, agricultores depauperados, y toda una serie de población, sobre todo alicantina, que ha encontrado en la otra orilla lo que en ésta no tenía. A lo largo de la historia, Argelia ha ido construyendo una cultura meridional mediterránea y sahariana de la que Alicante ha sido parte muy importante, $y$ donde el trasvase poblacional ha sido tradicionalmente de norte a sur.

Tras un final de siglo XX traumático para la historia de Argelia, el siglo XXI se presenta esperanzador para un país que, en un contexto de inestabilidad regional generalizado, desea por fin construir su prosperidad. $Y$ en este contexto se debe de acometer el estudio de Argelia en términos modernos, abandonando los planos soslayados o interesados, pues la constitución cultural y nacional argelinas forman a día de hoy una de las principales esferas y referentes de la modernidad árabe.

Los «Estudios Argelinos» representan un campo de estudios con notable tradición entendidos en su clave francófona, pero con escasa atención intrínseca tanto arabo-islámica como beréber. Y dentro de estos estudios, igualmente ha sido escasa la atención que la universidad española ha prestado a la cultura de uno de nuestros vecinos directos. Es por todo ello que el Área de Estudios Árabes e Islámicos de la Universidad de Alicante, 
desde su creación y atendiendo a sus mandatos fundacionales, ha tenido especial predilección por los Estudios Argelinos y la vinculación natural con el mundo académico de la orilla meridional. Desde Marcelino Villegas y Míkel de Epalza, principales referencias españolas en el conocimiento de la cultura argelina, con largas estancias en universidades de Argelia, hasta F. Franco-Sánchez, Luis Bernabé y Eva Lapiedra, y el establecimiento de convenios privilegiados entre instituciones de ambas orillas, la Universidad de Alicante ha seguido y sigue la realidad cultural de una sociedad que le es necesaria por naturaleza.

Es por todo ello que la creación de una publicación especializada exclusivamente en el fomento de los Estudios Argelinos parezca necesaria y natural a la historia y cometidos de la Universidad de Alicante. Con tal objeto se presenta «Revista Argelina», publicación semestral compuesta por ensayos, artículos y notas, reseñas y comentarios bibliográficos, y sección de biblioteca, buscando cumplir un mandato ineludible y cubrir un espacio necesario para la agitación, dinamización, reflexión y estudio de la cultura histórica y presente del pueblo argelino.

ISAAC DONOSO 